\begin{tabular}{|l|l||r||}
\hline Al Fitrah & Bagaimana Manajemen \\
\hline & Kurikulum PAUD di RA Al-Haq \\
& Pematang gubernur \\
Journal Of Early Childhood Islamic Education & Sarinah, Dini \\
ISSN : 2599-2287 E-ISSN : 2622-335X & Febrini, Ahmad Syarifin \\
\hline
\end{tabular}

\title{
BAGAIMANA MANAJEMEN KURIKULUM PENDIDIKAN ANAK USIA DINI DI RA AL-HAQ PEMATANG GUBERNUR KOTA BENGKULU
}

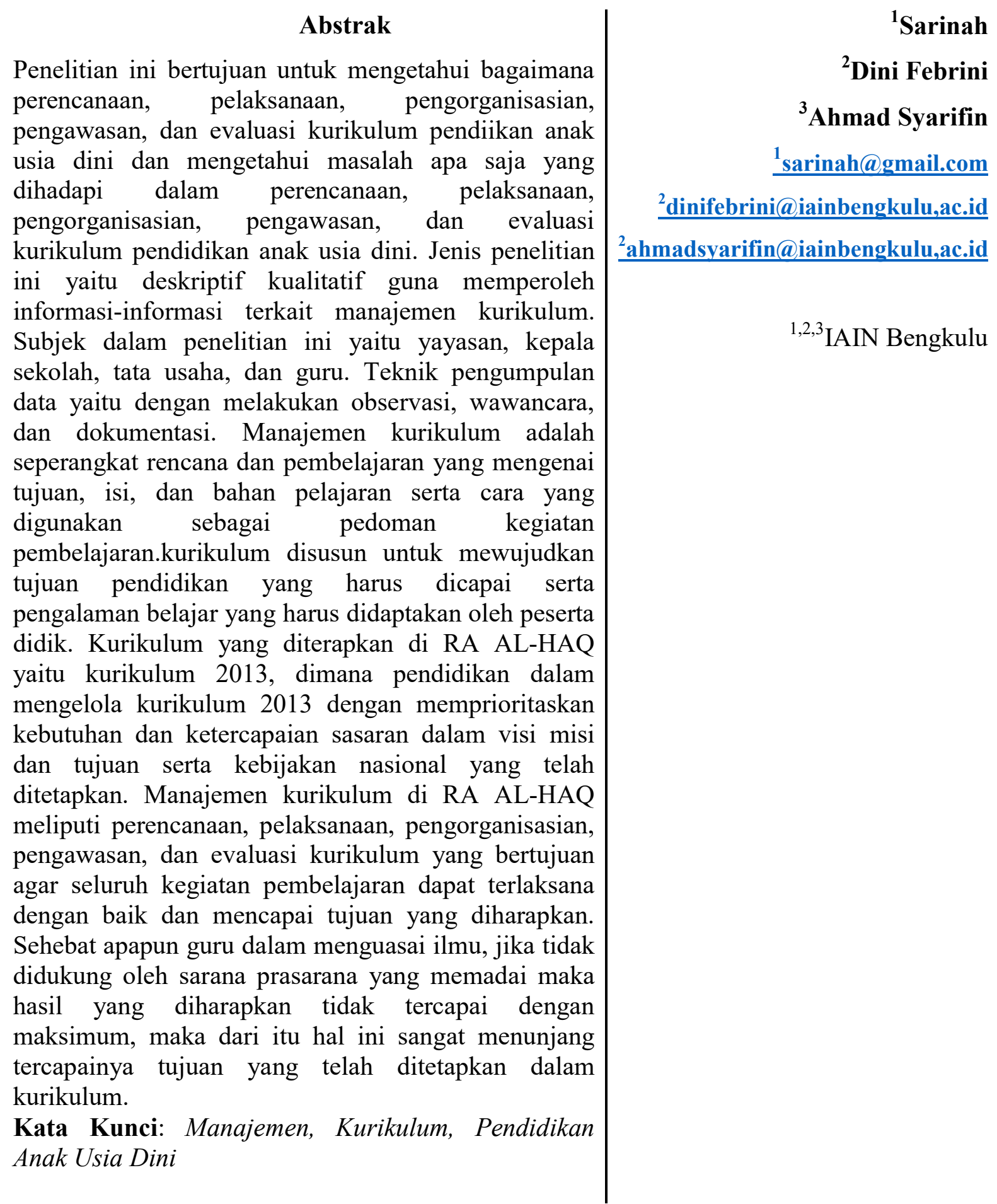




\begin{tabular}{|l|l|r|}
\hline A1 Fitrah & Bagaimana Manajemen \\
\hline Journal Of Early Childhood Islamic Education & Kurikulum PAUD di RA Al-Haq \\
ISSN : 2599-2287 E-ISSN : 2622-335X & Pematang gubernur \\
Sarinah, Dini \\
Vol.2 No.1 Juli 2018 & Febrini, Ahmad Syarifin \\
\hline
\end{tabular}

\section{Pendahuluan}

Merujuk pada UU No 20 Tahun 2003 tentang sistem Pendidikan Nasional, dinyatakan bahwa pendidikan terdiri atas Pendidikan Anak Usia Dini, pendidikan menengah, dan pendidikan tinggi, yang keseluruhannya merupakan kesatuan yang sistemik. Artinya, pendidikan harus dimulai dari usia dini, yaitu Pendidikan Anak usia Dini (PAUD). Dengan demikian, PAUD diselenggarakan sebelum jenjang pendidikan dasar. ${ }^{1}$

Pendidikan anak usia dini pada hakikatnya ialah pendidikan yang diselenggarakan dengan tujuan untuk memfasilitasi pertumbuhan dan perkembangan anak secara menyeluruh atau menekankan pada pengembangan seluruh aspek kepribadian anak. Oleh karena itu, PAUD memberi kesempatan kepada anak untuk mengembangkan kepribadian dan potensi secara maksimal. Pendidikan anak usia dini juga dapat diartikan sebagai salah satu penyelenggaraan pendidikan yang menitikberatkan pada peletakan dasar kearah pertumbuhan dan perkembangan. ${ }^{2}$

$$
\begin{aligned}
& \text { Pendidikan adalah segala } \\
& \text { pengalaman hidup dalam berbagai } \\
& 1 \text { Suyadi, Psikologi Belajar PAUD }
\end{aligned}
$$

lingkungan yang berpengaruh positif bagi perkembangan individu yang berlangsung. Pendidikan itu berlangsung sejak anak usia dini dan terus berlanjut sampai pada jenjang pendidikan yang lebih lanjut. ${ }^{3}$ Mutu bangsa dikemudian hari bergantung pada pendidikan yang dikecap oleh anakanak sekarang, terutama melalui pendidikan formal yang diterima di sekolah, apa yang diterima di sekolah, apa yang akan dicapai di sekolah, dan ditentukan oleh kurikulum.

Agar pelajaran berhasil dengan baik setiap anak harus diberikan perhatian dan bantuan serta guru harus mengenal pribadi setiap anak. Pengajaran setiap bidang harus disertai oleh pengenalan atas anak-anak yang menerimanya. Untuk mengenal anak dan mengembangkan pribadi anak kearah sikap yang positif terhadap belajar agar dapat meningkatnkan prestasinya. Guru tidak cukup hanya menguasai materi bahan pelajaran akan tetapi guru juga harus mampu melibatkan pribadi anak dalam pelajaran untuk mencapai hasil yang diharapkan. ${ }^{4}$

Kualifikasi guru bertujuan untuk mewujudkan tujuan pendidikan anak usia dini agar berhasil secara memuaskan.

\footnotetext{
${ }^{3}$ Masitoh, dkk, Strategi Pembelajaran TK, (Banten: Universitas terbuka, 2004), h. 1.3

4 Nasution, Berbagai Pendekatan Dalam Proses Belajar \& Mengajar, (Jakarta: Bumi Aksara, 1992), h. 122-123.
} 


\begin{tabular}{|c|c|c|}
\hline & $\begin{array}{l}\text { A1 Fitrah } \\
\text { Journal Of Early Childhood Islamic Education } \\
\text { ISSN : } 2599-2287 \text { E-ISSN : 2622-335X } \\
\text { Vol.2 No.1 Juli } 2018\end{array}$ & $\begin{array}{r}\text { Bagaimana Manajemen } \\
\text { Kurikulum PAUD di RA Al-Haq } \\
\text { Pematang gubernur } \\
\text { Sarinah, Dini } \\
\text { Febrini, Ahmad Syarifin }\end{array}$ \\
\hline
\end{tabular}

Karena guru memegang peranan sentral, maka kualitas guru harus ditentukan lewat pendidikan khusus yang sudah dipersiapkan. Guru juga diharapkan mampu mengarahkan, membangkitkan, dan mendorong potensi anak sampai pada level tinggi dari dimensi emosional, intelektual, dan spiritual sesuai perkembangan anak. ${ }^{5}$

Kurikulum adalah seperangkat rencana dan pengaturan mengenai tujuan, isi, dan bahan pelajaran serta cara yang digunakan sebagai pedoman penyelenggaraan kegiatan pembelajaran untuk mencapai tujuan pendidikan tertentu. ${ }^{6}$

Kurikulum berfungsi sebagai pedoman dalam melaksanakan proses pembelajaran. Kurikulum dipersiapkan untuk siswa dalam rangka memberi pengalaman baru yang dapat dikembangkan seiring dengan perkembangan anak. Bagi guru kurikulum dipergunakan sebagai pedoman kerja dalam menyusun dan mengorganisasikan pengalaman belajar bagi anak, mengadakan evaluasi terhadap

\footnotetext{
5 Jamal Ma'mur Asmani, Buku Pintar Playgroup, (Yogyakarta: Buku Biru, 2010), h. 131.

${ }^{6}$ Rusman, Manajemen Kurikulum, (Jakarta: PT Rajagrafindo Persada, 2009), h. 3
}

perkembangan anak serta mengatur kegiatan dan pengajaran. ${ }^{7}$

Penerapan kurikulum sebagai bagian integral dalam pengembangan kurikulum yang membutuhkan konsepkonsep, prinsip-prinsip dan prosedur serta pendekatan dalam manajemen. Implementasi kurikulum menuntut pelaksanaan pengorganisasian, koordinasi motivasi, pengawasan, sistem penunjang serta sistem komunikasi dan monitoring yang efektif, secara berasal dari ilmu manajemen. Dengan kata lain, tanpa memberdayakan konsep-konsep manajemen secara tepat maka penerapan kurikulum tidak berlangsung secara efektif.

Dalam proses pendidikan perlu dilaksanakan manajemen kurikulum agar perencanaan, pelaksanaan dan evaluasi kurikulum berjalan dengan efektif, efisien, dan optimal dalam memberdayakan berbagai sumber belajar, pengalaman belajar, maupun komponen kurikulum.

$$
\text { Ditinjau dari psikologi }
$$
perkembangan, usia prasekolah merupakan fase perkembangan individu sekitar 2-6 tahun, ketika anak mulai memiliki kesadaran tentang dirinya sebagai pria atau

7 Suyadi dan Dahlia, Implementasi dan Inovasi Kurikulum PAUD 2013 Program Pembelajaran Berbasis Multiple Intelligences, (Bandung: PT. Remaja Rosdakarya, 2014), h. 3. 


\begin{tabular}{|l||l|r|}
\hline A1 Fitrah & Bagaimana Manajemen \\
\hline Journal Of Early Childhood Islamic Education & Kurikulum PAUD di RA Al-Haq \\
ISSN : 2599-2287 E-ISSN : 2622-335X & Pematang gubernur \\
Sarinah, Dini \\
Vol.2 No.1 Juli 2018 & Febrini, Ahmad Syarifin \\
\hline
\end{tabular}

wanita, anak dapat mengatur dirinya dalam buang air, mengenal beberapa hal yang dianggap berbahaya, dapat mengembangkan keterampilan fisiknya, mampu mengendalikan emosi, dapat berkomunikasi dengan baik, serta dapat menanmkan nilai-nilai agama karena pada masa ini lah yang paling subur untuk menanamkan rasa agama kepada anak. ${ }^{8}$

Dalam Islam, tujuan pendidikan adalah membentuk manusia supaya sehat, cerdas, patuh dan tunduk kepada perintah Tuhan serta menjauhi larangan-laranganNya. Sehingga ia dapat berbahagia hidupnya lahir batin, dunia akhirat. ${ }^{9}$ Umumnya agama seseorang ditentukan oleh pendidikan melalui permainan, pengalaman, kebiasaan dan lingkungan yang dilaluinya pada masa kecilnya dulu. ${ }^{10}$ Salah satu kunci keberhasilan pengelolaan PAUD adalah melaksanakan kurikulum sesuai dengan tujuan pendidikan.

RA AL-HAQ merupakan salah satu jenjang pendidikan Anak usia Dini yang diselenggarakan melalui jalur pendidikan formal. RA Al-HAQ ini dibawah yayasan HAQIQI yang mana lembaga ini sudah

${ }^{8}$ Syamsu Yusuf, Psikologi Perkembangan Anak \& Remaja, (Bandung: PT Remaja Rosdakarya, 2014), h.162.

${ }^{9}$ Abu Ahmadi dan Nur Uhbiyati, Ilmu Pendidikan, (Jakrta: Rineka Cipta, 2001), h.99.

${ }^{10}$ Syamsu Yusuf, Psikologi Perkembangan Anak \& Remaja, (Bandung: PT Remaja Rosdakarya, 2014), h.178 berdiri sejak tahun 2006. Pendidikan yang dilaksanakan di RA AL-HAQ lebih difokuskan pada peletakan dasar-dasar pengembangan Imtaq, sikap, pengetahuan, keterampilan, dan daya cipta sesuai dengan pertumbuhan dan perkembangan anak. Dalam penerapan kurikulumnya, sekolah ini mencoba menyeimbangkan antara IQ, EQ, dan juga SQ dari peserta didik. Selain belajar di kelas sentra, pelaksanaan pembelajaran juga dilaksanakan di luar kelas (outdoor) dengan metode bermain. Karena pada dasarnya, masa kanak-kanak adalah masa untuk bermain. RA ALHAQ beralamatkan di jalan WR. Supratman Nomor 26 RT. 03 RW. 01 Kelurahan Pematang Gubernur Kecamatan Muara Bangkahulu Kota Bengkulu. ${ }^{11}$

Tenaga pengajar yang ada di RA AL-HAQ ini berjumlah 9 orang, 7 orang perempuan dan 2 orang laki-laki diantaranya yaitu lulusan S1 dan S2 pendidikan dan hukum. Sedangkan siswanya berjumlah 49 orang diantaranya 28 siswa laki-laki dan 21 siswa perempuan dan di RA. AL-HAQ ini memiliki 5 ruangan kelas yaitu B1 dengan jumlah siswa 9 anak laki-laki dan 2 anak perempuan, B2 dengan jumlah siswa 5 anak lakilaki dan 5 anak perempuan, B3 dengan jumlah siswa 6 anak laki-laki dan 4

${ }^{11}$ Lirwana, SP,. M.TPD, Kepala Sekolah $R A$ $A L-H A Q$ 


\begin{tabular}{|l|l||r||}
\hline & Al Fitrah & Bagaimana Manajemen \\
Journal Of Early Childhood Islamic Education & Kurikulum PAUD di RA Al-Haq \\
ISSN : 2599-2287 E-ISSN : 2622-335X & Pematang gubernur \\
Sarinah, Dini & Febrini, Ahmad Syarifin \\
\hline
\end{tabular}

anak perempuan, A1 dengan jumlah siswa 2 anak laki-laki dan 6 anak perempuan, dan A2 dengan jumlah siswa 6 anak lakilaki dan 4 anak perempuan. Kualitas siswa akan dapat tercapai sesuai dengan harapan jika ditunjang dengan adanya manajemen kurikulum yang berkualitas pula. Kurikulum di sini mencakup tentang perencanaan, pengorganisasian, pelaksanaan, pengawasan dan evaluasi kurikulum. $^{12}$

Kurikulum yang digunakan yaitu kurikulum 2013, penerapan kurikulum 2013 ini sudah diterapkan sejak tahun 2015. Pelaksanaan kurikulum di sekolah ini cukup baik, sehingga anak-anak dapat mengikuti aturan-aturan dengan baik serta guru dapat menerapkannya dalam pembelajaran. Model pembelajaran yang di terapkan di RA ALHAQ ini yaitu model pembelajaran sentra. ${ }^{13}$ Pembelajaran model sentra dikenal dengan istilah Beyond Centres and Circle Time (BCCT) merupakan kegiatan pembelajaran yang berpusat pada sentra bermain ketika anak berada dalam lingkaran. Dalam model pembelajaran ini guru mengahadirkan dunia nyata ke dalam kelas dan mendorong anak mengorelasikan antara pengetahuan yang dimilikinya dengan penerapan

\footnotetext{
${ }^{12}$ Lili Nusanti, Guru RA $A L-H A Q$

${ }^{13}$ Sri Arfayati, S.Pd Guru RA AL-HAQ
}

kehidupan seharihari. 14 Memasuki langkah-langkah kegiatan, terdapat beberapa kegiatan yang harus dilaksanakan oleh guru dalam mendukung terlaksananya model pembelajaran sentra, yaitu menata lingkungan bermain, kegiatan sebelum masuk kelas, pembukaan, transisi, kegiatan inti (pijakan sebelum bermain, pijakan selama bermain, dan pijakan setelah bermain), istirahat/makan, kegiatan penutup, dan penilaian. ${ }^{15}$

Berdasarkan uraian di atas maka penulis tertarik untuk mengetahui lebih jauh tentang manajemen kurikulum yang memfokuskan pada perencanaan, pengorganisasian, pelaksanaan, pengawasan dan evaluasi kurikulum di RA AL-HAQ Pematang Gubernur Kota Bengkulu. Dalam hal ini penulis mengambil judul tentang "Bagaimana

\section{Manajemen kurikulum Pendidikan}

Anak Usia Dini di RA AL-HAQ

Pematang Gubernur Kota Bengkulu”.

\section{Manajemen Kurikulum}

a. Pengertian manajemen

\footnotetext{
${ }^{14}$ Suyadi dan Dahlia, Implementasi dan Inovasi Kurikulum PAUD 2013: Proses Pembelajaran Berbasis Multiple Intelligences, (Bandung: Rosda, 2014), h.49

${ }^{15}$ Suyadi dan Dahlia, Implementasi dan Inovasi Kurikulum PAUD 2013: Proses Pembelajaran Berbasis Multiple Intelligences, (Bandung: Rosda, 2014), h. 51
} 


\begin{tabular}{|l||l|r|}
\hline A1 Fitrah & Bagaimana Manajemen \\
\hline Journal Of Early Childhood Islamic Education & Kurikulum PAUD di RA Al-Haq \\
ISSN : 2599-2287 E-ISSN : 2622-335X & Pematang gubernur \\
Sarinah, Dini \\
Vol.2 No.1 Juli 2018 & Febrini, Ahmad Syarifin \\
\hline
\end{tabular}

Kata manajemen berasal dari Bahasa Inggris, yaitu management dengan kata kerja to manage, diartikan secara umum sebagai mengurusi. ${ }^{16}$ Manajemen berhubungan dengan pembagian tugas dan pelimpahan wewenang atau tanggungjawab suatu pekerjaan. Kata manajemen terkandung tiga makna, yaitu pikiran, tindakan dan sikap. Sedangkan secara istilah kata manajemen dapat diartikan sebagai keterampilan, kerjasama, saling memfasilitasi agar dapat bekerja secara efektif dan efesien. ${ }^{17}$

b. Pengertian Kurikulum

Kurikulum merupakan semua hal yang menyangkut semua kegiatan yang dilakukakn dan dialami oleh peserta didik dalam perkembangan, baik formal maupun informal guna untuk mencapai tujuan pendidikan. ${ }^{18}$ Konsep kurikulum berkembang sejalan dengan perkembangan teori dan praktik pendidikan.

c. Pengertian Manajemen Kurikulum

16 Novan Ardy Wiyani dan Siswadi, Manajemen Program Kegiatan PAUD Berbasis Otak Kanan,

(Yogyakarta: Gava Media, 2018) cet-1. h.11

17 Novan Ardy Wiyani dan Siswadi, Manajemen Program Kegiatan PAUD h.13

18 Trianto, Desain Pengembangan Pembelajaran Tematik Bagi Anak Usia Dini TK/RA \& Anak Usia

Kelas Awal SD/MI. (Jakrta : Prenada Media Group, 2011). h. 103
Manajemen kurikulum adalah seperangkat rencana dan pembelajaran mengenai tujuan, isi, dan bahan pelajaran serta cara yang digunakan sebagai pedoman penyelenggaraan kegiatan pembelajaran untuk mencapai tujuan pendidikan tertentu.. Dalam pelaksanaannya, manajemen kurikulum harus dikembangkan sesuai dengan konteks Manajemen Berbasisi Sekolah (MBS) dan Kurikulum Tingkat Satuan Pendidikan (KTSP). ${ }^{19}$

d. Fungsi Manajemen Kurikulum

$$
\text { Fungsi-fungsi manajemen }
$$
merupakan proses yang sangat mempengaruhi keberhasilan manajemen. Ada beberapa macam fungsi manajemen kurikulum diantaranya adalah sebagai berikut :

1. Perencanaan Kurikulum

$$
\text { Perencanaan kurikulum }
$$

adalah perencanaan kesempatankesempatan belajar yang dimaksudkan untuk membina siswa ke arah tingkat perubahan tingkah laku yang diinginkan dan menilai

\footnotetext{
${ }^{19}$ (Jakarta: PT Rajagrafindo Persada, 2009),
} h. 3 


\begin{tabular}{|l|l|}
\hline A1 Fitrah \\
Journal Of Early Childhood Islamic Education \\
ISSN : 2599-2287 E-ISSN : 2622-335X \\
Vol.2 No.1 Juli 2018 \\
\hline
\end{tabular}

sampai mana perubahan-perubahan telah terjadi pada diri siswa. ${ }^{20}$

Perencanaan kurikulum memiliki multi fungsi, diantaranya sebagai berikut:

$>$ Perencanaan kurikulum berfungsi sebagai pedoman atau alat manajemen untuk mencapai tujuan.

Perencanaan kurikulum berfungsi sebagai penggerak roda organisasi dan tatalaksana untuk menciptakan perubahan dalam masyarakat sesuai tujuan organisasi.

Perencanaan kurikulum berfungsi sebagai motivasi untuk melaksanakan sistem pendidikan sehingga mencapai hasil maksimal. ${ }^{21}$

Keberhasilan perencanaan sangat menunjang atas keberhasilan kegiatan manajemen secara keseluruhan.

2. Pengorganisasian Kurikulum

Fungsi pengorganisasian sangat berkaitan dengan fungsi perencanaan, sebab pengorganisasian juga harus direncanakan terlebih dahulu.

20 Rusman, Manajemen

Kurikulum, (Jakarta: PT

Rajagrafindo Persada, 2009), h.

2121 Oemar Hamalik, Manajemen Pengembangan Kurikulum, h.152.
Bagaimana Manajemen Kurikulum PAUD di RA Al-Haq Pematang gubernur

Sarinah, Dini

Febrini, Ahmad Syarifin

Organisasi kurikulum

sangat terkait dengan pengaturan bahan pelajaran yang ada dalam kurikulum, sedangkan yang menjadi sumber bahan pelajaran dalam kurikulum adalah nilai budaya, nilai sosial, aspek siswa dan masyarakat, serta ilmu pengetahuan dan teknologi. ${ }^{21}$

3. Pelaksanaan Kurikulum

Untuk melaksanakan dan menguji kurikulum dalam kegiatan pembelajaran di kelas merupakan perwujudan bentuk kurikulum yang nyata. Perwujudan konsep, prinsip dan aspek kurikulum seluruhnya terletak pada kemampuan guru sebagai implementator kurikulum. Implementasi kurikulum yaitu karakteristik kurikulum, strategi implementasi, karakteristik penilaian, pengetahuan guru tentang kurikulum, sikap terhadap kurikulum serta ketrampilan dalam mengarahkan.

4. Pengawasan Kurikulum

Meskipun sebuah rencana telah disusun dengan matang dan dikerjakan secara organisatoris, akan tetapi kedua hal tersebut belum menjamin sebuah rencana

${ }^{21}$ (Jakarta: PT Rajagrafindo Persada, 2009), 


\section{Al Fitrah \\ Journal Of Early Childhood Islamic Education ISSN : 2599-2287 E-ISSN : 2622-335X Vol.2 No.1 Juli 2018}

dapat terealisasi dengan baik. Agar rencana dapat terealisasi dengan baik maka perlu adanya kontrol atau pengendalian yang dikerjakan oleh seorang pengawas. Seorang pengawas harus mampu memberikan motivasi, mengarahkan, memperbaiki, dan upaya-upaya lain yang positif ke semua komponen yang terlibat dalam realisasi perencanaan. ${ }^{22}$

5. Evaluasi Kurikulum

Evaluasi kurikulum merupakan bagian dari proses kurikulum yang berlangsung secara berkesinambungan dan merupakan keterpaduan dari semua dimensi pendidikan dalm rangka mencapai tujuan pendidikan yang telah ditetapkan. Proses tersebut berlangsung secara bertahap dan berjenjang. Evaluasi kurikulum meliputi: komponen-komponen analisis kebutuhan dan kelayakan, perencanaan dan pengembangan, proses pembelajaran, revisi kurikulum, dan research kurikulum. $^{23}$

22 Suyadi, Manajemen PAUD TPA-KBTK/RA, (Yogyakrta: Pustaka Pelajar. 2011), h.79.

${ }^{23}$ (Jakarta: PT Rajagrafindo Persada, 2009),
Bagaimana Manajemen Kurikulum PAUD di RA Al-Haq Pematang gubernur

Sarinah, Dini Febrini, Ahmad Syarifin

Adapun definisi kurikulum evaluasi adalah perbuatan pertimbangan berdasarkan seperangkat kriteria yang disepakati dan dapat dipertanggungjawabkan. Ada satu prinsip umum dan penting dalam kegiatan evaluasi, yaitu adanya triangulasi atau hubungan erat tiga komponen, yaitu:

a) Tujuan pembelajaran;

b) Kegiatan pembelajaran atau $\mathrm{KBM}$, dan

c) Evaluasi

e. Teori manajemen

Teori manajemen dapat membantu menunjukkan profesi manajemen. Kerja sama antara teoretisi manajemen dan praktisi manajemen dapat membuahkan hasil yang mengagumkan.

Teori ini memfokuskan perhatiannya pada studi waktu untuk setiap pekerjaan (time and motion study).

f. Indikator keberhasilan

Keberhasilan yang dalam pengembangannya memberikan kewenangan sangat besar kepada sekolah melalui pengambilan keputusan partisipatif, sehingga sangat ditentukan oleh kepala sekolah, guru, dan siswa h. $94-95$ 


\begin{tabular}{|c|c|c|}
\hline & $\begin{array}{l}\text { A1 Fitrah } \\
\text { Journal of Early Childhood Islamic Education } \\
\text { ISSN : } 2599-2287 \text { E-ISSN : 2622-335X } \\
\text { Vol.2 No.1 Juli } 2018\end{array}$ & $\begin{array}{r}\text { Bagaimana Manajemen } \\
\text { Kurikulum PAUD di RA Al-Haq } \\
\text { Pematang gubernur } \\
\text { Sarinah, Dini } \\
\text { Febrini, Ahmad Syarifin }\end{array}$ \\
\hline
\end{tabular}

yang terlibat secara langsung dalam pengelolaan manajemen kurikulum.

\section{Metode Penelitian}

1. Jenis Penelitian

Penelitian ini merupakan penelitian kualitatif yakni salah satu prosedur penelitian yang menghasilkan data deskriptif berupa ucapan dan tulisan dan perilaku orang-orang yang diamati. $^{24}$

Penelitian deskriptif memusatkan perhatian pada masalah actual sebagaimana adanya pada saat penelitian berlangsung. Melalui penelitian ini, peneliti berusaha mendeskripsikan peristiwa dan kejadian yang menjadi pusat perhatian tanpa memberikan perlakuan khusus terhadap peristiwa tersebut. ${ }^{25}$ Penelitian ini juga disebut penelitian survei, merupakan metode formal untuk memperoleh informasi yang ditempuh dengan penyebaran angket atau wawancara secara pribadi serta dengan observasi terhadap subyek penelitian.

Penelitian survei tidak hanya digunakan untuk melukiskan kondisi yang ada, tetapi juga untuk

\footnotetext{
${ }^{24}$ Wiratna Sujarweni, Metodologi Penelitian, (Yogyakarta: PT. Pustaka Baru, 2014), h.19

${ }^{25}$ Juliansyah Noor, Metodologi Penelitian: Skripsi, Tesis, Disertasi dan Karya Ilmiah, (Jakarta: Prenada Media Group, 2011), h.35
}

membandingkan keadaan tersebut dengan kriteria yang telah ditetapkan atau menilai keefektifan program. Dengan kata lain penelitian deskriptif kualitatif ini bertujuan untuk memperoleh informasi-informasi terkait manajemen kurikulum di RA AL-HAQ Pematang Gubernur Kota Bengkulu.

2. Tempat dan Waktu Penelitian

Tempat penelitian yaitu RA ALHAQ Secara administratif RA AL-HAQ beralamatkan di jalan WR. Supratman No. 26 Rt. 03 Rw. 01 Kelurahan Pematang Gubernur Kecamatan Bangkahulu Kota Bengkulu. Yang dilaksanakan kurang lebih satu bulan terhitung dari tanggal 24 April sampai dengan tanggal 05 Juni 2018.

\section{Pembahasan}

Manajemen kurikulum merupakan suatu rencana yang disusun untuk melancarkan proses belajar mengajar di bawah bimbingan dan tanggung jawab sekolah atau lembaga penididikan beserta staf pengajarnya. ${ }^{26}$ Kurikulum disusun untuk mewujudkan tujuan pendidikan yang harus dicapai serta pengalaman belajar yang harus didapatkan oleh para peserta didik. Pendidikan yang diterapkan di RA AL-HAQ ini adalah pendidikan dalam

$$
{ }^{26} \text { Nasution, (1989: 5) }
$$




\begin{tabular}{|l|l|r|}
\hline A1 Fitrah & Bagaimana Manajemen \\
\hline Journal Of Early Childhood Islamic Education & Kurikulum PAUD di RA Al-Haq \\
ISSN : 2599-2287 E-ISSN : 2622-335X & Pematang gubernur \\
Sarinah, Dini \\
Vol.2 No.1 Juli 2018 & Febrini, Ahmad Syarifin \\
\hline
\end{tabular}

mengelola kurikulum 2013 dengan

berlaku

secara

nasional, memprioritaskan kebutuhan dan mengembangkan perangkat ketercapaian sasaran dalam visi misi dan tujuan RA AL-HAQ serta tidak mengabaikan kebijakan nasional yang telah ditetapkan. Manajemen kurikulum di RA AL-HAQ meliputi perencanaan, pelaksanaan, pengorganisasian, pengawasan, dan evaluasi kurikulum yang bertujuan agar seluruh kegiatan pembelajaran dapat terlaksana dengan baik sesuai dengan yang telah ditetapkan. ${ }^{27}$

1) Perencanaan

Perencanaan kurikulum adalah kegiatan yang berkaitan dengan usaha, perumusan suatu program yang didalamnya memuat sesuatu yang dilaksanakan, penentuan tujuan, kebijakan arah, prosedur, dan tujuan yang harus ditempuh. ${ }^{28}$ Perencanaan kurikulum ini juga menyangkut penetapan tujuan dan memperkirakan cara pencapaian tujuan tersebut. Perencanaan kurikulum, secara nasional menjadi tugas Depdiknas dan secara lokal menjadi tugas Dinas Pendidikan, sedangkan tugas sekolah dalam perencanaan kurikulum adalah memahami standar kompetensi yang

${ }^{27}$ Hasil Wawancara dengan Ibu Lirwana, SP.M.,TPD, 30-04-2018, di Kepala Sekolah, (09.00-10.30)

${ }^{28}$ Terry (2005: 1)

pembelajaran sesuai dengan kondisi siswa, mengembangkan materi bahan ajar, merumuskan indikator pencapaian kompetensi, dan mengembangkan instrumen-instrumen penilaian.

Berdasarkan hasil wawancara proses perencanaan di RA AL-HAQ yaitu sebelum merencanakan kurikulum kepala sekolah dan guru melakukan kordinasi lalu mengadakan rapat awal tahun, yang mana dalam rapat awal tahun inilah kepala sekolah dan guru membahas mengenai persiapan dan apa yang akan direncanakan untuk satu tahun kedepan. Perencanaan disini mencakup program tahunan, program semester, perencanaan mingguan, dan perencanaan harian. Dimana sebelum dilakukan proses pembelajaran guru RA AL-HAQ harus sudah memahami terlebih dahulu tentang program penididikan yang ingin dicapai.

Kemudian dari hasil yang telah direncanakan ini akan di aplikasikan kedalam kegiatan pembelajaran seharihari dalam bentuk nilai karakter terhadap anak sesuai dengan visi misi dan tujuan RA AL-HAQ. Kepala sekolah dan guru sangat terlibat halnya 
dalam merencanakan kurikulum ini, karena yang akan mengaplikasikan pembelajaran dikelas adalah guru. ${ }^{29}$ Adapun langkah-langkah yang dilakukan sebelum merencanakan kurikulum adalah menyiapkan apa-apa yang dibutuhkan seperti halnya media yang sesuai dengan tema, kemudian dikorelasikan lagi dengan visi misi serta tujuan yang ingin dicapai.

Kurikulum ini bertujuan untuk mempersiapkan anak agar memiliki kemampuan hidup sebagai pribadi yang beriman, produktif, kreatif, inovatif, dan afektif serta mampu berkontribusi dengan masyarakat.

Berdasarkan hasil wawancara perencanaan kurikulum di RA ALHAQ memiliki tujuan yang jelas dan spesifik, dimana perencanaan kurikulum ini juga harus disesuaikan dengan sasaran peserta didik, kemampuan tenaga kependidikan, dan perkembangan masyarakat. Perencanaan kurikulum ini juga memperhatikan keseimbangan antara kemampuan dan program yang akan dilaksanakan, bahkan dapat memberikan kemudahan bagi siswa melalui bahan ajar. perencanaan

${ }^{29}$ Hasil Wawancara dengan Ibu Lirwana, SP.M.,TPD, 30-04-2018, di Kepala Sekolah, (09.00-10.30) kurikulum disini memuat perangkat pembelajaran yang bermutu, sehingga dapat meningkatkan mutu proses belajar anak dan kualitas lulusan secara keseluruhan. ${ }^{30}$

Berdasarkan hasil penelitian, perencanaan kurikulum di RA ALHAQ ini telah terdokumentasi dengan baik, adapun permasalahan yang dihadapi dalam perencanaan yaitu:

a) Pembuatan RPPH yang dibuat oleh guru masih kurang kreatif. RPPH yang dibuat oleh guru seharusnya sesuai dengan standar yang ingin dicapai.

b) Tidak semua guru melengkapi semua yang ada pada RPPH bahkan ada beberapa guru yang tidak membuat RPPH. Ketidak disiplinan guru menjadikan kurang tertibnya pembuatan RPPH, dalam hal ini perlu adanya pengontrolan dari kepala sekolah terkait pembuatan RPPH agar pelaksanaan pembelajaran terlaksana dengan baik.

c) Sulitnya memahami RPPM untuk dijadikan RPPH. Membuat RPPH harus mengacu pada RPPM, tidak hanya di salin akan tetapi dapat

${ }^{30}$ Hasil Wawancara dengan Ibu Lirwana, SP.M.,TPD, 30-04-2018, di Kepala Sekolah, (09.00-10.30) 


\begin{tabular}{|l||l|r|}
\hline A1 Fitrah & Bagaimana Manajemen \\
\hline Journal Of Early Childhood Islamic Education & Kurikulum PAUD di RA Al-Haq \\
ISSN : 2599-2287 E-ISSN : 2622-335X & Pematang gubernur \\
Sarinah, Dini \\
Vol.2 No.1 Juli 2018 & Febrini, Ahmad Syarifin \\
\hline
\end{tabular}

mempertimbangkan segala aspek pembelajaran. Meskipun dalam pelaksanaan proses pembelajaran berjalan dengan lancar, namun merancang kegatan harian harus tetap ditulis. RPPH tersebut akan dijadikan sebagai kontroling guru dalam pembelajaran.

2) Pelaksanaan

Pelaksanaan kurikulum ini merupakan hasil terjemahan guru terhadap kurikulum yang telah dijabarkan dalam perencanaan pembelajaran dan rencana pelaksanaan sebagai rencana tertulis.

Berdasarkan hasil wawancara pelaksanaan kurikulum di RA ALHAQ sesuai dengan apa yang telah direncanakan, strategi pembelajaran di RA AL-HAQ ini sesuai dengan model pembelajaran yang diterapkan yaitu model pembelajaran sentra. Dimana model pembelajaran sentra ini dengan menggunakan metode praktek dan metode penugasan anak akan lebih aktif, karena dalam kurikulum k-13 ini anak harus lebih aktif dan guru hanya memfasilitasi saja. ${ }^{31}$

Dalam pelaksanaan kurikulum yang menjadi faktor utama adalah

\footnotetext{
${ }^{31}$ Hasil Wawancara dengan Ibu Lili Nusanti, S.Pd, 01-05-2018, di Ruang Kelas B2, (08.00-10.00)
}

guru. Dimana guru harus memiliki kualifikasi yang baik dan kompetensi yang baik.

Berdasarkan hasil wawancara faktor yang mendukung dalam pelaksanaan ini adalah seluruh guru dan ketenaga pendidikan. Adapun guru di RA AL-HAQ ini mayoritasnya S1 dan ada beberapa yang lulusan S2, adapun kualifikasinya S1 PAUD, S1 Pendidikan, dan S2 Hukum. Akan tetapi semua guru ini sudah sering diikut sertakan dalam pelatihanpelatihan tentang PAUD maka semua guru di RA AL-HAQ ini meskipun bukan lulusan PAUD tapi mereka mampu memahami tumbuh kembang anak dan mereka memahami bagaimana cara memberikan pembelajaran yang asyik terhadap anak agar anak tidak bosan saat belajar. $^{32}$

Kebijakan pemerintah terhadap kurikulum biasanya hanya untuk penataan lembaga, guru yang berprestasi, terkait dengan bahan ajar serta ketersediaan sarana dan prasarana.

Menurut hasil wawancara di RA AL-HAQ untuk kebijakan

${ }^{32}$ Hasil Wawancara dengan Ibu Lirwana, SP.M.,TPD, 30-04-2018, di Kepala Sekolah, (09.00-10.30) 


\begin{tabular}{|l|l||r||}
\hline Al Fitrah & Bagaimana Manajemen \\
\hline & Kurikulum PAUD di RA Al-Haq \\
& Pematang gubernur \\
Journal Of Early Childhood Islamic Education & Sarinah, Dini \\
ISSN : 2599-2287 E-ISSN : 2622-335X & Febrini, Ahmad Syarifin \\
\hline
\end{tabular}

pemerintah, alhamdulillah pemerintah sudah memfasilitasi dengan adanya K13, kurikulu Raudhatul Athfal dari Kementrian Agama maupun dari Kementrian Pendidikan seperti halnya dalam Permendikbud 146 tentang Kurikulum 2013 Pendidikan Anak Usia

Dini. $^{33}$

Tujuan kurikulum ini untuk mendorong perkembangan perkembangan peserta didik sehingga mempunyai kesiapan untuk menempuh jenjang pendidikan yang lebih lanjut.

Berdasarkan hasil wawancara tujuan diberlakukannya kurikulum di RA ALHAQ adalah sebagaimana akan mewujudkan visi misi dan tujuan RA AL-HAQ, yang mana dalam visi misi tersebut ingin membentuk generasi islami yang berkarakter sehat, cerdas, dan ceria menuju masa depan yang berkualitas. $^{34}$

\section{Pembelajaran}

sentra merupakan model pembelajaran yang berfokus pada anak. Pada pembelajarannya menggunakan 4 jenis

${ }^{33}$ Hasil Wawancara dengan Ibu Lirwana, SP.M.,TPD, 30-04-2018, di Kepala Sekolah, (09.00-10.30)

${ }^{34}$ Hasil Wawancara dengan Ibu Lirwana, SP.M.,TPD, 30-04-2018, di Kepala Sekolah, (09.00-10.30) pijakan yaitu pijakan lingkungan bermain, pijakan sebelum bermain, pijakan selama bermain, dan pijakan setelah bermain.

Berdasarkan hasil wawancara strategi pembelajaran yang digunakan di RA ALHAQ sesuai dengan model pembelajaran sentra yang mana anak diharuskan untuk lebih aktif dan guru hanya memfasilitasi saja. Adapun pada saat pembelajaran anak melakukan pijakan lingkungan bermain terlebih dahulu, lalu anak melakukan pijakan sebelum bermain dimana guru menjelaskan terlebih dahulu cara dan aturan bermain,setelah itu anak melakukan pijakan selama bermain yang mana pada pijakan ini guru hanya memperhatikan dan anak yang melakukan dengan mandiri, lalu setelah itu pijakan setelah bermain, dimana guru meminta anak untuk membereskan permainan lalu guru menanyakan perasaan anak tentang permainan yang sudah dilakukan anak. $^{35}$

Untuk alokasi waktu biasanya dimasukkan kedalam program tahunan, dimana penetapan alokasi waktu ini untuk mengetahui pencapaian tujuan standar kompetensi

${ }^{35}$ Hasil Wawancara dengan Ibu Lili Nusanti, S.Pd, 01-05-2018, di Ruang Kelas B2, (08.00-10.00) 


\begin{tabular}{|l||l|r|}
\hline A1 Fitrah & Bagaimana Manajemen \\
\hline Journal Of Early Childhood Islamic Education & Kurikulum PAUD di RA Al-Haq \\
ISSN : 2599-2287 E-ISSN : 2622-335X & Pematang gubernur \\
Sarinah, Dini \\
Vol.2 No.1 Juli 2018 & Febrini, Ahmad Syarifin \\
\hline
\end{tabular}

dan kompetensi dasar selama satu tahun. Untuk pembelajaran dikelas terkain media pembelajaran guru harus menyesuaikan media dengan tema yang telah direncanakan. ${ }^{36}$

Sebuah pelaksanaan ini akan berjalan dengan baik jika direncanakan semaksimal mungkin dan terlaksana sesuai rencana. Rencana yang baik memang tidak akan selalu sempurna dan pasti akan terdapat permasalahan dalam pelaksanaan pembelajaran. Permasalahan dalam pelaksanaan di RA AL-HAQ, diantaranya yaitu:

a) Tidak adanya jadwal jam tambahan untuk kegiatan ekstrakurikuler. Sehingga jika ada kegiatan ekstrakurikuler harus menggunakan jam belajar efektif, hal tersebut membuat kurang kondusifnya kegiatan belajar mengajar. Penyajian materi harusnya berdasarkan kurikulum yang sudah ditetapkan. Jika ekstrakurikuler dimasukkan pada jam pembelajaran, maka pelaksanaannya tidak sesuai dengan perencanaan.

b) Dalam proses pembelajaran masih terdapat guru yang kurang kreatif memanfaatkan sarana prasarana serta

${ }^{36}$ Hasil Wawancara dengan Ibu Lili Nusanti, S.Pd, 01-05-2018, di Ruang Kelas B2, (08.00-10.00) media pembelajaran yang telah tersedia.

Komponen lain yang mempengaruhi kelancaran pelaksanaan kurikulum adalah sarana prasarana, penyediaan sarana prasarana yang memadai bisa menunjang hasil pembelajaran yang baik. Sehebat apapun guru dalam menguasai ilmu pengetahuan dan teknologi, jika tanpa didukung oleh sarana prasarana yang memadai maka hasil yang diharapkan tidak tercapai secara maksimum. Oleh karena itu, dalam pelaksanaan kurikulum hal ini harus diperhatikan agar dapat menunjang tercapainya tujuan yang telah ditetapkan dalam kurikulum.

3) Pengorganisasian

Organisasi kurikulum ini merupakan struktur program kurikulum yang berupa kerangka umum program-program pengajaran yang di sampaikan kepada peserta didik guna tercapainya tujuan pendidikan atau pembelajaran yang telah ditetapkan.

Berdasarkan hasil wawancara pengorganisasian kurikulum di RA AL-HAQ telah dilakukan melalui rapat kordinasi antara guru dan tenaga kependidikan. Kepala sekolah, guru, dan tata usaha sangat berperan didalam 
mengorganisasikan kurikulum.

Dimana guru harus mengkondisikan sejauh mana kesiapan pembelajaran, APE yang digunakan harus sesuai dengan tema, ruang pembelajaran harus di tata rapi agar anak merasa aman dan nyaman saat pembelajaran berlangsung, kemudian guru harus memahami strategi pembelajaran agar anak tidak merasa bosan, sehingga ketika diorganisasikan secara utuh kurikulum itu terlaksana. ${ }^{37}$ Dalam hal ini anak sangat terlibat dalam pengorganisasian kurikulum karena anak adalah sebagai sasaran yang dituju.

Pengorganisasian kurikulum meliputi semua hal yang menyeluruh yang dilakukan untuk mewujudkan kegiatan yang telah direncanakan menjadi suatu struktur tugas, wewenang dan menentukan siapa yang akan melaksanakan tugas serta siapa yang dapat mencapai tugas yang diinginkan dalam organisasi.

4) Pengawasan

Pengawasan kurikulum merupakan suatu sistem pengumpulan dan penerimaan informasi berdasarkan data yang tepat, akurat, dan lengkap

${ }^{37}$ Hasil Wawancara dengan Ibu Lirwana, SP.M.,TPD, 30-04-2018, di Kepala Sekolah, (09.00-10.30) tentang pelaksanaan kurikulum yang dilaksanakan secara efesien dan melalui tahapan yang tepat dalam jangka waktu tertentu.

Berdasarkan hasil wawancara pengawasan kurikulum di RA ALHAQ melalui tahapan supervisi yang dilakukan oleh kepala sekolah terhadap pembelajaran yang dilakukan oleh guru. Mulai dari perencanaan, pelaksanaan, kemudian pengorganisasian ini semua dilakukan pengawasan lalu di evaluasi. Kepala sekolah mengevaluasi guru dan tata usaha. Hal ini biasanya dilakukan oleh kepala sekolah setiap satu semester dengan menggunakan metode observasi maupun dilihat dari pencapaian hasil anak selama satu semester. Tujuan diadakannya pengawasan ini agar kita dapat mengevaluasi unsur kurikulum mana yang belum tercapai dan yang harus diperbaiki untuk kedepannya. 38 Dimana strategi pengawasan dapat dilakukan secara berkala dan berkelanjutan serta melalui proses.

Sedangkan pengawasan terhadap anak dilakukan oleh guru yang dilaksanakan setiap hari saat

${ }^{38}$ Hasil Wawancara dengan Ibu Lirwana, SP.M.,TPD, 30-04-2018, di Kepala Sekolah, (09.00-10.30) 


\begin{tabular}{|l||l|r|}
\hline A1 Fitrah & Bagaimana Manajemen \\
\hline Journal Of Early Childhood Islamic Education & Kurikulum PAUD di RA Al-Haq \\
ISSN : 2599-2287 E-ISSN : 2622-335X & Pematang gubernur \\
Sarinah, Dini \\
Vol.2 No.1 Juli 2018 & Febrini, Ahmad Syarifin \\
\hline
\end{tabular}

pembelajaran dan mengacu pada rencana pelaksanaan pembelajaran harian (RPPH). Tujuannya untuk dapat mencapai tujuan yang telah direncanakan sehingga dapat tercapai dengan baik. Bentuk pengawasannya melalui catatan anekdot, yang mana dalam satu hari biasanya hanya tiga anak kemudian dilanjutkan di hari esok, maka dari itu kepala sekolah menghimbau keseluruh guru untuk pengawasan melalui catatan anekdot diberi jangka waktu dalam satu minggu. ${ }^{39}$

\section{Pengawasan yang seharusnya} yaitu melalui proses tahapan pemantauan, supervisi, dan pelaporan, yang mana pemantauan yang dilakukan untuk kegiatan perencanaan, kegiatan pelaksanaan pembelajaran dan kegiatan hasil belajar siswa. Supervisi dilakukan untuk proses pembuatan perencanaan yang dibuat oleh guru, pelaksanaan pembelajaran dikelas, dan penilaian hasil belajar. Kemudian pelaporan yang harus memuat hasil-hasil kegiatan dari

\footnotetext{
${ }^{39}$ Hasil Wawancara dengan Ibu Lili Nusanti, S.Pd, 01-05-2018, di Ruang Kelas B2, (08.00-10.00)
}

pemantauan, supervisi hingga evaluasi proses pembelajaran. ${ }^{40}$

Tujuan pengawasan yaitu menstandarkan pelaksanaan kerja, melindungi asset organisasi, mempertahankan kualitas produk, membatasi jumlah kewenangan pimpinan dan pegawai, dan mengarahkan kinerja pegawai dan unit kerjanya, sebagian dilakukan melalui penilaian prestasi kerja, pengamatan, supervisi langsung dan melaporkan hasil kerjanya baik yang bersifat kualitatif maupun kuantitatif.

Akan tetapi tahapan pengawasan yang dilakukan di RA AL-HAQ ini hanya menggunakan tahapan supervisi saja, seharusnya kepala sekolah juga melakukan pemantauan dan pelaporan sehingga pengawasan yang dilakukan sesuai dengan apa yang telah direncanakan dan ditetapkan dalam kurikulum. Dan untuk tujuan pengawasan seharusnya catatan anekdot ditulis setiap hari per anak, akan tetapi dikarenakan waktu yang tidak memungkinkan untuk hal itu.

5) Evaluasi

${ }^{40}$ Hasil Wawancara dengan Ibu Lirwana, SP.M.,TPD, 30-04-2018, di Kepala Sekolah, (09.00-10.30) 


\begin{tabular}{|c|c|c|}
\hline & $\begin{array}{l}\text { Al Fitrah } \\
\text { Journal Of Early Childhood Islamic Education } \\
\text { ISSN : 2599-2287 E-ISSN : 2622-335X } \\
\text { Vol.2 No.1 Juli } 2018\end{array}$ & $\begin{array}{r}\text { Bagaimana Manajemen } \\
\text { Kurikulum PAUD di RA Al-Haq } \\
\text { Pematang gubernur } \\
\text { Sarinah, Dini } \\
\text { Febrini, Ahmad Syarifin }\end{array}$ \\
\hline
\end{tabular}

Evaluasi kurikulum merupakan bagian dari proses kurikulum yang berlangsung secara berkesinambungan dan merupakan keterpaduan dari semua dimensi pendidikan dalam rangka untuk mencapai tujuan pendidikan yang telah ditetapkan. Proses evaluasi ini berlangsung secara berjenjang.

Berdasarkan hasil wawancara proses evaluasi kurikulum di RA ALHAQ dilaksanakan baik bulanan maupun semester. Kepala sekolah mengevaluasi guru dan tata usaha sejauh mana intrumen persiapan, pelaksanaan dan perencanaan kurikulum berjalan. Biasanya kepala sekolah mengevaluasi dalam satu bulan khusus mengevaluasi KBM berkaitan dengan kurikulum yang direncanakan. ${ }^{41}$

Kemudian guru melakukan pengamatan setiap perubahan tingkah laku yang ada pada anak. Selain itu juga, guru dapat mengevaluasi anak disaat ia bermain dan belajar. Evaluasi dilakukan setiap hari setelah proses pembelajaran yang meliputi aspek pembiasaan, kognitif, seni, bahasa, fisik motorik yang dimasukkan ke

${ }^{41}$ Hasil Wawancara dengan Ibu Lirwana, SP.M.,TPD, 30-04-2018, di Kepala Sekolah, (09.00-10.30) dalam RPPH. Sementara untuk laporan perkembangan anak kepada orang tua yaitu dalam bentuk

Raport yang diberikan setiap satu semester. $^{42}$

Alat penilaian yang digunakan oleh guru RA AL-HAQ adalah sebagai berikut:

1. Catatan anekdot, Penilaian yang berdasarkan pengamatan dan ting kah laku anak dari jam kedatangan hingga anak pulang.

2. Tanya jawab, Penilaian ini berdasarkan hasil percakapan anatara guru dan anak.

3. Portofolio, Penilaian berdasarkan pengumpulan hasil kerja anak yang dapat menggambarkan sejauh mana anak berkembang.

4. Unjuk kerja, Penilaian yang menuntut anak untuk melakaukan tugasnya dalam perbuatan yang dapat diamati, contohnya anak praktek menyanyi dan memperagakan sesuatu/gerakan.

5. Penugasan, Tugas yang harus dikerjakan anak dan memerlukan waktu yang cukup lama dalam pengerjaannya. Contohnya anak melakukan percobaan.

6. Hasil karya, Hasil kerja anak setelah melakukan suatu kegiatan.

${ }^{42}$ Hasil Wawancara dengan Ibu Lili Nusanti, S.Pd, 01-05-2018, di Ruang Kelas B2, (08.00-10.00) 


\begin{tabular}{|l||l|r|}
\hline A1 Fitrah & Bagaimana Manajemen \\
\hline Journal Of Early Childhood Islamic Education & Kurikulum PAUD di RA Al-Haq \\
ISSN : 2599-2287 E-ISSN : 2622-335X & Pematang gubernur \\
Sarinah, Dini \\
Vol.2 No.1 Juli 2018 & Febrini, Ahmad Syarifin \\
\hline
\end{tabular}

Contohnya anak membuat kolase. $^{43}$

Akan tetapi, berdasarkan penelitian permasalahan yang ada pada evaluasi yaitu memaksimalkan evaluasi, evaluasi bukan sekedar menilai akan tetapi evaluasi akan dijadikan sebagai bahan perbaikan dan peningkatan pada setiap peserta didik.

\section{Kesimpulan}

Berdasarkan hasil penelitian dan pembahasan, maka penulis dapat menyimpulkan:

1. Perencanaan kurikulum di RA ALHAQ berjalan lancar sebagaimana mestinya. Kepala sekolah dan para dewa guru merencanakan kurikulum pada awal tahun ajaran baru, yang dimulai dari pembuatan program tahunan, program semester, RPPM, dan RPPH. Guru melaksanakan pembelajaran berdasarkan dengan perencanaan yang sudah ditetapkan. Pengorganisasian kurikulum telah dilakukan dengan sebuah upaya yang terkait dengan pengorganisasian materi atau bahan ajar dan pengorganisasian kelas. Kepala sekolah melakukan pengawasan terhadap guru tidak setiap hari akan tetapi kepala sekolah selalu

\footnotetext{
${ }^{43}$ Hasil Wawancara dengan Ibu Lili Nusanti, S.Pd, 01-05-2018, di Ruang Kelas B2, (08.00-10.00)
}

menghimbau kepada guru ketika ada masalah segera di diskusikan bersama dan pengawasan terhadap anak dilakukan oleh guru kelas setiap hari. Evaluasi kurikulum dilakukan oleh kepala sekolah menggunakan metode observasi dan diadakan rapat setiap semester, dan guru mengevaluasi peserta didik setiap hari setelah pembelajaran.

2. Permasalahan yang dihadapi dalam perencanaan yaitu guru mengalami kesulitan dalam memahami RPPM yang akan dijadikan RPPH. Dalam pelaksanaan yaitu kurangnya kreativitas guru dalam pembelajaran, kurangnya alokasi waktu untuk kegiatan, serta kurangnya media pembelajaran. Dalam pengorganisasian yaitu masih kurangnya pemahaman guru terhadap penggunaan IT terkait dengan kurikulum. Dalam pengawasan yaitu masih kurangnya waktu untuk pengawasan, sehingga catatan anekdot bagi peserta didik sehari hanya tercapai tiga anak. Dalam mengevaluasi adanya beda pendapat diantara tim dan kurang maksimalnya evaluasi yang dilakukan guru terhadap peserta didik.

\section{DAFTAR PUSTAKA}

Ahmadi, Abu dan Nur Uhbiyati. 2001. Ilmu Pendidikan. Jakarta: Rineka Cipta 


\begin{tabular}{|l|l|r|}
\hline Al Fitrah & Bagaimana Manajemen \\
\hline & Kurikulum PAUD di RA Al-Haq \\
& Pematang gubernur \\
Sournal Of Early Childhood Islamic Education & Sarinah, Dini \\
ISSN : 2599-2287 E-ISSN : 2622-335X & Febrini, Ahmad Syarifin \\
\hline
\end{tabular}

Aini, 'Nur. 2013. "Urgensi Pendidikan Anak Usia Dini Dalam Mempersiapkan Ke Jenjang Pendidikan Dasar (Studi Kasus Pada Kelompok Bermain: Kelas Matahari PAUD Griya Nanda UIN Sunan Kalijaga Yogyakarta). (Skripsi, Fakultas Ilmu Keguruan, Uin Sunan Kalijaga).

Amrillah, M. Fikri 2013. "Efektifitas Pembelajaran PAI Melalui Media Lagu Di PAUD Lestari

Plipiran Bruno Purworejo".

(Skripsi, Fakultas Ilmu Tarbiyah dan Keguruan, UIN Sunan Kalijaga)

Asmani, Jamal Ma'mur. 2010. Buku Pintar Playgroup. Yogyakarta: Buku Biru.

Bafadal, Ibrahim. 2004. Dasar-dasar Manajemen dan Supervisi Taman Kanak-kanak. Jakrta: PT. Bumi Aksara

Hamalik, Oemar. 2008. Manajemen Pengembangan Kurikulum. Bandung: PT Remaja Rosdakarya.

Hamalik, Oemar. 2001. Proses Belajar Mengajar. Jakarta: PT Bumi Aksara

Hanafi, Mamduh. 2008. Manajemen. Yogyakrta: UPP-AMP YKPN.

Hapidin, dkk. 2010. Manajemen Pendidikan TK. Jakarta: Universitas Terbuka.

J. Moleong, Lexy. 2009. Metode Penelitian Kualitatif. Bandung: PT Remaja Rosdakarya
Maryani. 2004. "Peranan Ibu Pada Pendidikan Anak Usia Dini Dalam Perspektif Islam. (Skripsi, Fakultas Tarbiyah IAIN Sunan Kalijaga).

Masitoh, dkk. 2004. Strategi Pembelajaran TK. Banten: Universitas Terbuka.

Mansur. 2005. Pendidikan Anak Usia Dini dalam Islam. Yogyakarta: Pustaka Pelajar.

Muliawan, Jasa Unggulan. 2014. Metodelogi Penelitian Pendidikan Dengan Studi Kasus. Yogyakarta: Penerbit Gava Media.

Mulyasa. 2009. Implementasi kurikulum tingkatan satuan pendidikan, kemandirian guru dan kepala sekolah. Jakarta: Bumi Aksara.

Nasution. 1992. Berbagai Pendekatan Dalam Proses Belajar \& Mengajar. Jakarta: PT. Bumi Aksara.

Nasution. 2011. Metode Research (Penelitian Ilmiah). Jakarta: PT. Bumi Aksara.

Noor, Juliansyah. 2011. Metodologi Penelitian: Skripsi, Tesis, Disertasi dan Karya Ilmiah. Jakarta: Prenada Media Group.

Nurani Sujiono, Yuliani. 2009. Konsep Dasar Pendidikan Anak Usia Dini. Jakarta: PT Indeks.

Peraturan Menteri Pendidikan Nasional RI No. 58 Tahun 2009 Tentang Standar PAUD.

Peraturan Pemerintah No. 17 Tahun 2010 tentang pengelolaan dan 


\begin{tabular}{|l||l|r|}
\hline A1 Fitrah & Bagaimana Manajemen \\
\hline Journal Of Early Childhood Islamic Education & Kurikulum PAUD di RA Al-Haq \\
ISSN : 2599-2287 E-ISSN : 2622-335X & Pematang gubernur \\
Sarinah, Dini \\
Vol.2 No.1 Juli 2018 & Febrini, Ahmad Syarifin \\
\hline
\end{tabular}

Penyelenggaraan Pendidikan Pasal 61, Ayat (1).

Peraturan Pemerintah RI Nomor 32 tahun 2013 Tentang Perubahan Atas Peraturan Pemerintah.

Sugiyono. 2014. Metode Penelitian Kuantitatif, Kualitatif dan R\&D. Bandung: Alfabeta.

Sujarweni, Wiratna. 2014. Metodologi Penelitian. Yogyakarta: PT. Pustaka Baru

Sukmadinata, Nana Syaodih. 2017. Pengembangan Kurikulum Teori dan Praktik. Bandung: PT Remaja Rosdakarya.

Suyadi. 2014. Implementasi dan Inovasi Kurikulum PAUD 2013: Proses Pembelajaran Berbasis Multiple Intelligences. Bandung: Rosda.

Suyadi. 2013. Konsep Dasar PAUD. Bandung: PT. Remaja Rosdakarya.

Suyadi. 2011. Manajemen PAUD TPA-KB$T K / R A$. Yogyakarta: Pustaka Pelajar.

Suyadi. 2009. Psikologi Belajar PAUD (Pendidikan Anak Usia Dini). Yogyakarta: Pedagogia.

Suyadi. 2014. Teori Pembelajaran Anak Usia Dini Dalam Kajian Neurosains. Bandung: PT Remaja Rosdakrya.

Trianto. 2011.. Desain Pengembangan Pembelajaran Tematik Bagi Anak Usia Dini TK/RA dan Anak Usia Kelas Awal SD/MI. Jakarta: Prenada Media.

Wiyani, Novan Ardy dan Siswadi. 2018. Manajemen Program Kegiatan
PAUD Berbasis Otak Kanan. Yogyakarta: Gava Media

Yusuf, Syamsu. 2014. Psikologi Perkembangan Anak \& Remaja. Bandung: PT Remaja Rosdakarya. 